\title{
Journalist on the Line of Fire: Scrutinizing Contemporary Military Journalism with Philosophical Anthropology Approach
}

\author{
Il'ia A. Bykov \\ Saint Petersburg State University, Saint Petersburg, Russia; Email: i.bykov@spbu.ru \\ Andrei Y. Dorskii \\ Saint Petersburg State University, Saint Petersburg, Russia \\ Sergei I. Shelonaev \\ Saint Petersburg State University of Technology and Design, Saint Petersburg, Russia \\ Andrei V. Ulianovskii \\ Saint Petersburg State University, Saint Petersburg, Russia
}

Doi:10.5901/mjss.2015.v6n5s2p105

\section{Abstract}

This study examines transformations in contemporary military journalism, applying philosophical anthropology approach. Increasing contradictions between special status of journalist and generated by reporters contextual-true information clearly produce all sorts of anthropological problems in the mass media. The simple fact of journalist's presence at the location of military conflict creates the phenomenon of hunting on journalist, which highly increase the risk of injuries, kidnappings, and brutal deaths among military journalists. Conflicting sides are able to use death of journalist against each other. Philosophical anthropology as a school of thinking treats human life as a most valuable thing, considering all social and scientific facts from human point of view. The article proposes, on the basis of philosophical analysis, to start new way of development for military journalism in the beginning of the 21st century. This way bases mostly on the development of drone technology for the purposes of military journalism. The authors insist that future military journalist is to be consider as an operator of drones with all necessary for reporting audio- and video-equipment.

Keywords: military journalism, information warfare, drone technology, philosophical anthropology, contextual-true information

\section{Introduction}

Journalist as a peaceful, non-violent, deliberative observer is an agent of freedom of speech, specially trained for figuring out and revealing of reasonable objectivity (Glasser, 1996). Journalist is a person who operates as a mechanism of correct conversion of analog information from the physical environment of our presence to the global digital information environment. In this scheme of communication flows journalist is a living operator of information, gatekeeper between the real life and the reality of mass media (Bourdieu, 1998).

Mentioned above functions are changing dramatically when journalist goes to report about wars or military conflicts (Gjelten, 1998). At the field of armed conflict journalist usually belongs to the one side of conflicting forces. Due to the fact of significant (both actual and relative) increase in time of media exposure of digital information environment, journalist's professional activity are the main weapon in contemporary large-scale information wars. In its turn information "ammunition", the energy of these weapons (reports, news, talk-shows, etc.) supplied information regarding the local conflicts. It is the global nature of the dissemination of information in digital form which defines new trend: the physical localization of the military conflict is often so far removed from the viewer that it has very little significance in the life-world of the audience, which, as Abraham Mole used to insist, is so poor in critical perception that consume it as a spectacle or a show (Moles, 1969). Therefore, journalist became to behave as an information soldier with high level of entertainment.

More over, there is another important side of military journalism. Military reporter depends on hosting side for reasons of security and sources of information. For these reasons the dependency is rather strong (Markham, 2011). 
Contemporary military forces tends to use this dependency for public relations purposes. E. g., during Persian Gulf War "the U.S. military was taking on board some 600 reporters", which is relatively big number (Wilford, 2009, 23).

At the same time, according to the Geneva Conventions, journalists are protected under international humanitarian law. War correspondents are recognized as non-combatant relative to the Treatment of Prisoners of War, and some journalists are civilians relative to the Protection of Civilian Persons in Time of War (Geneva Conventions, 1949). The situation in the world after 1949 has significantly changed, and we should recognize that international law in the part of military correspondents is not ready. So, today the fighting takes place not only on the battlefield but in the media as well. And if we consider the mass media as means of consciousness destruction, the definition of a combatant could be applicable to many journalists. And the other party takes every reason to regard them as combatants. On the other hand, lack of military training and journalistic activities make from reporter an easy target in the area of armed conflict. Here, a phenomenon of hunting on journalists emerges. Conflicting sides are able to use a possible death of a given journalist against each other, blaming opposite side for killing. That's why there are so many deaths among military journalists all around the world. For example, the UN Security Council reported recently that 25 journalists were killed in the situations of armed conflict since the beginning of 2015, and about 700 - during the last 10 years (Adopting Resolution, Security Council Condemns Violence against Journalists, Urges End to Impunity, 2015).

The main objective of the study is to explore transformations in contemporary military journalism toward hightechnological profession, applying advanced drone technology to collect and to report necessary information. At the same time military journalism still must appeal to the human feelings and attitudes. The authors believe that in order to solve this task the philosophical anthropology has one of the best methodological framework.

\section{Methods}

Philosophical anthropology methodology roots deeply in the history of philosophy since the times of Ancient Greece when Protagoras used to say that "Man is the measure of all things: of things which are, that they are, and of things which are not, that they are not" (Plato, Theaetetus, 152a). Here we can see basic difference between philosophical anthropology and scientific positivism. Search for a special human nature, based on the "human biological failure", which forces man to create a culture, an artificial side of nature (including equipment) is the most important, but not the only side of the philosophical and anthropological analysis (M. Heidegger, M. Scheler, H. Plessner, A. Gelen, M. Buber, etc). Anthropological conceptual framework has two basic principles: first, the anthropological reduction (substantiation of a way of human existence in the modern situation, the disintegration of the structure of life, reduction of human existence to the field of culture) and, second, the principle of practical and activity-objectification with appropriate cultural forms (O.-F. Bolnow, W. Dilthey). Philosophical anthropology comes from the fact that person must know himself not through direct self-observation, in the spirit of Schopenhauer, and thanks to the practical social-cultural objectification, through the prism of introduced, created his own cultural images, ideas and things. Therefore the methodological intention of philosophical anthropology as a system of knowledge is about the person, synthesizing methodological approaches and conclusions of philosophy, psychology, cultural studies, sociology and history, as well as natural sciences, treated as the basis of this work.

The possibility of considering the creation of a social reality through human interactions substantiate philosophy of life and existentialism, which today becomes to be a part of philosophical anthropology. For example, A. Schopenhauer considered the world as a will and a representation. The world depends on the capabilities of knowing subject, therefore, man is the most perfect device in the objectification of the will. The development of this idea later leads to an understanding that man is a creature of the ascetics or eccentrically organized being located not in equilibrium, regardless of time and place, but in the nothingness. The position of Schopenhauer about the true irrational essence of things later develops to Heidegger's thought about installing the objectification of beings as the metaphorical basis of the New Age, which is characterized by accuracy of performance, plausibility or truth-likeliness rather than by the pursuit of truth. This is the world of modern things, accompanying human lusts and passions, and even science itself as it was proved in scientific studies of the sociology of knowledge (K. Mannheim), empirical falsification (K. Popper), ethnological studies of scientific practices (K. Knorr-Gethin), scientific and historical criticism of scientific and theoretical normativeness - theory of scientific paradigms (T. Kuhn). Therefore, philosophical anthropology tends to analyze human factor in the mass media, when reporter acts as a gatekeeper of information dissemination.

\section{Journalist's Existence and War}

It is worth to note that in the present conditions, the digital information about the conflict contributes to the victory of one 
side or another, it becomes victorious in the range of measures of its objectivity and truthfulness. Modern information technology can generate a range of statements close to the point of confusion, but not completely coincide with the true information. Obviously, modern computer technology has a great role in video- and photo-editing. Additionally, the situation can be complicated by the measure of the truthfulness of information in terms of time, the date and duration of the demand for its produced by audiences. In other words, visual truthful reporting from the scene "here and now" in the direct mode of operation can be less than truthful with a time lag of a few days, weeks, months, "there and then". The very existence of objective information in the information environment can produce a potential advantage in the information war. We are meaning the presence of any information on the subject, up to the inclusions of "no comment", running subtitles and non-linear editing.

Here we can see escalated conflict: journalist is a civilian in the physical analogue of a local conflict, but in a metaphysic form of the professional forces he is a tactical level officer in the digital environment of information warfare. Moreover, the tighter the flow of digital broadcast of similar messages in terms of increasing repetitions, frequency and coverage, the higher the inverse influence of digital media has on the physical reality. In this aspect, journalist becomes a hostage to the above-mentioned reverse effect due to the direct access to broadcasting. The journalist can be treated as "gatekeeper" of interchange between the physical analog environment and digital information space. It is really important that military journalist initiates report directly from the point at the same time of the event, but also its own unique status of person who directly conjugates with the situation is absolutely invaluable.

This ambivalent status of the journalist suggests a new and very rapid way to enter the broadcast with a nonconventional effect on the body of the journalist (death, e. g.) in the physical analog environment of a local conflict, and it almost automatically leads to a transfer of information about this very negative event together with all its negative connotations from one environment to another. This practice is fairly new and is contrary to the realities of the past century then large-scale wars have been occurred. Then death of journalist meant to convert information on the principle like: "journalist disappears - information disappears - no impact on the public opinion". Compare this with the new principle of our times: " journalist disappears - immediately negative information about it pumps - impact on the public opinion continues". The latter is possible in the conditions of local conflicts, when the entire infrastructure of transmission signals into the global digital space is efficient, accessible and has the character of the transmission of information in a continuous stream of data.

Summing up, we can assume that the reported by journalist information has objective status, but the damage to journalist's body produces powerful propaganda effect. We believe there are three possible ways of development in so dangerous correlation between the physical damage to journalist and the powerful propaganda news-brake, based on this tragic occasion.

\subsection{Military Journalism "from Second Hand"}

The first way is actively used at the moment, for example, by European mass media for coverage of the armed conflict in Eastern Ukraine. This way bases mostly on media outsourcing, where primary sources of information and news belong to local mass media. According to S. Shelonaev, world media space consists of three big zones: "center", "half-peripheral", and "peripheral" (Shelonaev, 2012). Journalists of digital media often belong to the so-called zone "Hard core" of hierarchical media close to the western media corporations. They remain outside the physical conflict zone and operate the information entered into the digital media environment by networked peripherals. This scheme is characterized by a catastrophic decline in quality, reliability and efficiency of broadcasting. As a matter of fact, this style of reporting as really close to the artistic genres of "parallel reality" and "fantasy". G. Merom calls this phenomenon "asocial wars" (Merom, 2012). Of course, such military journalism "from second hand", though saving reporters lives, carries along so many other problems for mass media that almost all of them tends to apply old, good school of military journalism.

\subsection{Military Journalism with the Risk to Life}

The second way is a genetic continuation of the traditional model of heroic conduct by military journalist. But the situation of local conflicts with a cost-effective digital information environment (infrastructure) available directly in the area of conflict is fundamentally different from that of full-scale war on the national territory and the conjugating territories. Under the conditions of full-scale war global digital information environment must be destroyed and fragmented inevitably (orbiting satellite explosions, issuing false GPS-coordinates, disabling transcontinental fiber-optic highways, radiojamming, Internet-filtering, etc.). Reporters of World War II acted in very different conditions than today's local conflict reporters. For example, an American reporter, Ernie Pyle, was a very famous war correspondent. He had a notable 
special courage - has always sought to be in the thick of things. Quickly becoming a friend among his soldiers, he was a little soldier. He died April 18, 1945 in Okinawa (Japan).

Modification of this way is used today by the Russian media in Eastern Ukraine. It includes advanced physical protection (upgraded body armors, helmets, secure communication), habits of behavior in the conflict zone, stealth and agility of movement of journalists in the area of local clashes. As a general hypothesis, we note that this way is only able to somewhat reduce the considered problem, but does not destroy it completely. In addition, it produces reduced volume of entertainment. There are many examples of TV-reports with a sound of an explosion behind the scenes on a static background, anecdotal stories in the style of "we do not see, but, over there, in the side of the parapet of the trench..." and too many replays of identical images, captured with a greater risk, with the sharply negative emotional coloring.

The second way of military journalism with high frequency of replays leads to a rejection of watching the news by spectators. Media research in the field of television advertising has shown that repeats more than 10-12 times bear the risk of rejection (Kolomiyets, 2001). It's especially strong within the case of negative information. To watch the same tragic story several times is unbearable. Low efficiency in military journalism is linked also to the presence of at least five to fifteen channels competing for the attention of the audience. This leads to an effect of active audience shifting from reportage with negative story to other channels and downgrade news on the transmitting channel. We assume that applying of high wartime propaganda technology to the digital channels of broadcasting in time of peace is short-sighted.

\subsection{Military Journalism with a Drone Technology}

The third way, we offer, has a character of humanitarian and social innovation. Perhaps, this is the right way, on the one hand, to maintain the accuracy of the reporting and keep high quality standards, and, on the other hand, to minimize the possibility of damage to the body of the journalist. To implement this scenario one need to ensure removal of the physical body of journalist from the zones of armed conflict with the ability to continue video- and audio-recording. This can be realized with such unmanned aerial vehicles (UAV) as drones (drones), equipped with TV- and audio-recorders. Cameraman became a drone operator, providing shooting angle by means of its positioning. At the same time sound recording goes with group of small drones. For this application, the drones are much more mobile than ground vehicles. This specialization could be called "drone journalism" by analogy with "television journalism or "radio journalism" (Khubetsova et al., 2015).

Similar scenario has been described in the last novel by V. Pelevin "S.N.U.F.F." (Pelevin, 2012) V. Pelevin insists that the future military journalist is to be a product of convergence between journalism, military pilot, advertising and public relations. All actions of the novel take place in a post-apocalyptic space, in "times of general decline and degradation". Society predominated by lie, which emerged as a result of the whole previous way of life. It was therefore invented a new tool - "snuff" - an information product that combines video and other events of the war scenes documentaries. The abbreviation "S.N.U.F.F." means "Special Newsreel / Universal Feature Film".

Particular attention in the novel is paid to the problem of differentiation between news and artwork: "...A miracle remote head allows you to transfer the attention wherever you go. It can cause a person to see any place, real or fictional. But there is a dividing line between reality and fantasy. It separates the movie from the news. Speaking crudely and simplistically, the news show that really is, film shows what is actually there. Together they have many times led the world to the war" (Pelevin, 2012, 359). Pelevin envisions perspectives of military journalism with drones as possible manipulating technology. Similar ethic implications about drone technology in journalism were questioned by K. Culver (Culver, 2014).

\section{Conclusion}

In conditions of local conflicts, when the entire information infrastructure is efficient and easily accessible, lethal impact on the body of the journalist almost automatically leads to a transfer of information about this very negative event together with all its negative context to the mass media. Journalism Heroes of World War II worked in the very different conditions than today local conflict, which enjoys all global information infrastructure. Reported by journalist information has objective status, but the damage to the body of the journalist produces powerful propaganda effect. Therefore, there is a pressing problem of hunting on military journalists. There are three possible ways of development:

a) military journalism "from second hand";

b) military journalism with the risk to life;

c) military journalism with a drone technology.

Our analysis shows that non of this three scenarios is able to solve the problem in principle. Removing living 
reporters from the line of fire by solving one particular difficulty generates too many others. From philosophical anthropology point of view the best way to deal with the matter is to produce such a political system which force to abstain from wars and military conflicts.

\section{References}

Adopting Resolution, Security Council Condemns Violence against Journalists, Urges End to Impunity. (2015) UN News Service Section. May 27. [Online] Available: http://www.un.org/apps/news/story.asp?NewsID=50980\#.VXmGDHWlyko. (June 1, 2011).

Bourdieu P. (1998) On Television and Journalism. London: Pluto Press.

Culver, K. B. (2014) From Battlefield to Newsroom: Ethical Implications of Drone Technology in Journalism. Journal of Mass Media Ethics. Vol. 29. No. 1: 52-64.

Geneva Conventions. (1949) [Online] Available: https://www.icrc.org/applic/ihl/ihl.nsf/385ec082b509e76c41256739003e636d/6756482d 86146898c125641e004aa3c5 (June 1, 2011).

Gjelten T. (1998) Professionalism in War Reporting: A Correspondent's View. New York: Carnegie Corporation of New York.

Glasser T. (1996) The Idea of Public Journalism. New York: Guildford Press.

Khubetsova Z., Korkonosenko S., Blokhin I. (2015) Journalistic Education: Conceptualization and Media Competences. Mediterranean Journal of Social Sciences. Vol. 6. No. 3 S3. P. 107-117.

Kolomiyets V. P. (ed.). (2001) Telereklamnyy biznes: informatsionno-analiticheskoye obespecheniye. Moscow: Mezhdunarodnyy institut reklamy.

Markham, T. (2011) The Political Phenomenology of War Reporting. Journalism. Vol. 12. No. 1: 567-85.

Merom, G. (2012) The Age of Asocial War: Democratic Intervention and Counterinsurgency in the Twenty-First Century. Australian Journal of International Affairs. Vol. 66. No. 3: 365-80.

Moles, A. (1973) Sociodynamique de la Culture. Paris: Mouton.

Pelevin V. (2012) S.N.U.F.F. Moscow: Eksmo

Shelonayev S. I. (2012) Mediprostranstvo: opyt sotsiologicheskogo analiza. Saint Petersburg: Asterion.

Wilford, M. (2009) The Big Story: Our Embattled Media. World Affairs. Vol. 172. No. 2: 22-35. 